Jurnal Ilmu dan Teknologi Kelautan Tropis, Vol. 8, No. 2, Hlm. 539-552, Desember 2016

\title{
HABITAT SUITABILITY AND ZONING ANALYSIS FOR GREEN TURTLE Chelonia mydas IN THE MARINE CONSERVATION AREAS OF PANGUMBAHAN TURTLE PARK, SUKABUMI
}

\author{
Yusuf Arief Afandy ${ }^{*}$, Fredinan Yulianda ${ }^{2}$, Syamsul Bahri Agus ${ }^{3}$, dan Lucy Peter Liew \\ ${ }^{1}$ Coastal and Marine Resources Studies, IPB; *E-mail: y.arief98@ gmail.com \\ ${ }^{2}$ Department of Aquatic Resources Management, IPB, Bogor \\ ${ }^{3}$ Department of Marine Science and Technology, IPB, Bogor \\ ${ }^{4}$ Danau Girang Field Center, Sabah, Malaysia
}

\begin{abstract}
ABSTRAK
Penelitian ini mengkaji tentang kesesuaian habitat penyu hijau di Kawasan Konservasi Perairan Taman Pesisir Pantai Pangumbahan. Tujuan penelitian ini untuk mengevaluasi sistem zonasi yang telah ada dan memberikan rekomendasi alternatif penataan zonasi berdasarkan pendekatan kesesuaian ekologi habitat penyu. Penelitian dilaksanakan di sepanjang kawasan Taman pesisir pantai Pangumbahan pada bulan Januari - Juni 2015 dengan melakukan pengumpulan data lokasi peneluran penyu, suhu dan kelembaban pasir, lebar pantai, kemiringan permukaan pantai, tutupan vegetasi pantai, lamun serta data sekunder. Metode analisis data terdiri dari analisis kesesuaian dengan pendekatan spasial menggunakan Sistem Informasi Geografis. Hasil analisa kesesuaian habitat penyu hijau terdiri dari 3 kelompok kelas kesesuaian, yaitu sangat sesuai seluas 6,91 hektar, sesuai seluas 14,60 hektar dan kelas tidak sesuai seluas 37,21 hektar. Zonasi kawasan konservasi yang telah ada saat ini perlu direvisi sesuai rekomendasi sistem zonasi. Sebagai bentuk implementasi hasil kajian serta untuk efektifitas pengelolaan kawasan wisata yang berbasis ekologi penyu hijau, direkomendasikan untuk dilakukan penataan zonasi yang mengedepankan prinsip kesesuain habitat untuk keberlanjutan penyu hijau di kawasan konservasi tersebut. Dengan menjadikan prinsip kesesuaian habitat penyu hijau sebagai dasar penentuan zonasi di dalam kawasan konservasi, zonazona yang dibuat di dalam kawasan konservasi akan sesuai dengan karakteristik penyu hijau, hal ini mampu memilah tiap zona sesuai dengan fungsi dan pengaruhnya terhadap penyu hijau.
\end{abstract}

Kata kunci: Chelonia mydas, penyu hijau, kesesuaian, konservasi, Pangumbahan

\begin{abstract}
This study reviews the suitability of habitat for the green turtle in the Pangumbahan Turtle Park. The purpose of this study is to evaluate the existing zoning system and to provide recommendations of alternative zoning approach based on ecological suitability turtle habitat. Observations and fieldwork were undertaken throughout the coastal area of Pangumbahan from January to June 2015 by collecting data which include nesting site for turtles, sand temperature and moisture content, width of the beach, surface slope of the beach, vegetation cover, seagrass and secondary data. Methods of data analysis consists of suitability analysis with the spatial approach using Geographic Information System. The results of the analysis of overlay method were classified into three classes of suitability, which include very suitable covering 6.91 hectares, suitable covering 14.60 hectares and less suitable covering 37.21 hectares. The current existing zones needs to be revised using the recommended zoning system. As an implementation of the findings from this study as well as to effectively manage the conservation area based on the green turtle ecology, it is highly recommended to do a zoning system which is based on the principal of the green turtles habitat suitability to ensure the sustainability of the green turtle within the conservation area. This will ensure the zoning system suits the green turtles' characteristics hence enabling each of the zones to effectively functioning.
\end{abstract}

Keywords: Chelonia mydas, green sea turtle, suitability, conservation, Pangumbahan 


\section{INTRODUCTION}

The International Union for Conservation of Nature (IUCN) has listed green turtles into the list of endangered species (IUCN, 2004), while Convention on International Trade in Endangered Species of Wild Fauna and Flora (CITES) has listed all sea turtle species in Appendix I which means they are prohibited from international trade. In the Indonesian archipelago, turtle distributed from Aceh to Papua (Nuitja, 1992). Green turtles are particularly found along the western coast of Indonesia. One of the place which is known to be turtles' distribution area and also a nesting place of the green turtle Chelonia mydas in Indonesia is the Pangumbahan beach, located in Sukabumi, West Java. There are several factors causing the decline of Green turtle populations, including the sea and land use changes, exploitation of eggs and body parts, the threat of predators, diseases, and improper conservation area management. Many marine species which have longer life cycles are more susceptible to exploitation (Bjorndal, et $a l ., 2005)$, and thus the long life cycle of a turtle makes it a species with high vulnerability level and that proper conservation of the turtles is essential and should be done urgently.

As a commitment to turtle conservation, the Pangumbahan beach is designated as a coastal park under the decree of the Sukabumi regent No: 523/Kep.639 Dislut$\mathrm{kan} / 2008$ which was issued on the $31^{\text {st }}$ December 2008 as Marine Conservation Area of Pangumbahan Turtle Park. The Minister of Marine Affairs and Fisheries inaugurated this area as Turtle Center on December 22,2009 . As part of the efforts to manage the protected areas for the conservation of green turtles, the coastal area of Pangumbahan Turtle Park have been divided into several zones including core zone, limited use and other zones. The core zone as a source of germplasm will be the only area that should be maintained to ensure its suitability as a natural habitat for the species. Until today, there have been a number of studies conducted in Pangumbahan beach, but none of these studies have done the evaluation of the zones within the conservation area. Geneletti and Duren (2008) had conducted a study in Paneveggion Pale in S. Martino Natural Park (Italy) which analyzed and evaluated zones through the combination of multi spatial criteria and multi objectives evaluation to determine the suitability of an area, which was then used as a basis in the process of evaluating and determining zones within a conservation area.

Effective spatial planning and zoning will ensure the protection of the turtle population in a region, however, too often the zones are not formed in accordance with the primary objectives of the establishment of protected areas which are crucial in synergizing the ecology, social and economy aspects. The inappropriate determination of a zone will only benefit one of the aspect and will give adverse effects on other aspects. A good understanding of patterns, habits and behaveor of sea turtles and their habitat characteristics are essential for the proper determination of the zones which will effecttively synergize the social and economical aspects. Fujisaki et al. (2016), stated that the green turtle habitat characteristics can be used to evaluate the suitability of a zone within a conservation area. Knowledge and research of the sea turtle ecology is particularly important for the Asian region where turtle populations have decreased dramatically and the under-standding of the turtles is still very low (Cheng et al., 2009). Structuring appropriate zoning would preserve the protected species as well as to make effective conservation management while providing sustainable benefits to the community. This study aims to analyse the suitability of habitat for green turtles to determine the core zone and to evaluation and provide recommendations on the zoning system based on the green turtle ecology approach in the conservation area of 
Pangumbahan Turtle Park to achieve effecttive management.

\section{METHODS}

Research was conducted within the green turtle conservation area in Pangumbahan Turtle Park of $2.7 \mathrm{~km}$ in length. Administratively, this location is located in the rural area of Pangumbahan, Ciracap, Sukabumi district, Western Java province between $7^{\circ} 17^{\prime} 08^{\prime \prime} \mathrm{S}-7^{\circ} 21^{\prime} 50^{\prime \prime} \mathrm{S}$ and $106^{\circ} 23^{\prime}$ $40^{\prime \prime E}-106^{\circ} 24$ ' $10^{\prime \prime} \mathrm{E}$. The research area was divided into 7 land unit stations (station 0 to station 6) and was conducted in three phases: determining data collection methods, data collection and data analysis. Data collection was divided into two step processes based on the type of measured parameters. First process was conducted for 6 months (January to June 2015), in which the number of green turtle nesting at each stations was recorded. The second process was conducted for 18 days in May 2015, in which ecological parameters of green turtle habitat suitability were gathered.

\subsection{Materials and Data}

The type of data used in this research were primary and secondary data.

\subsubsection{Primary Data}

Primary data are data obtained through observation or direct measurement in the field. The required primary data are include:

\section{The number of nests and nesting locations}

The coordinates of the nesting location was recorded using a GPS during night time for 6 months starting from January to June 2015. Using the number of nests recorded and than its location, a spatial distribution preferences of the green turtles during the 6 months period was developed and was used to explain the distribution of the green turtle population in Pangumbahan beach. The spatial distribution preferences of the green turtles is assumed as the habit and behavior of the green turtles. Using the number of nests recorded and its location, a hot spot map is developed to determine the density level of the green turtles which is illustrated as spots of three different colors which include red, white and blue spots. In brief each of these colors represents the density level of the green turtles: red (represent the hotspot or locations with the highest density of nests), white (represent medium density of nests) and blue (coldspot, represent the lowest density of nests). In this study, only data collected within a six months period were used due to no records of turtle nesting activities were made in the previous years. The acquired data from UPTD Pangumbahan shows only records of turtle nesting activities by months starting from the year 2007 to 2014, thus, could only show the frequency and trend of the green turtles' coming ashore and is not representtative of a the green turtles' spatial distribution preferences on Pangumbahan beach.

\section{Beach Vegetation}

Vegetated areas in the study region were digitised using the high resolution satellite imagery of Google Earth Pro in the study region. The higher resolution of the Google Earth images enabled better interpretation ability and therefore permitted the classification of the vegetation coverage into three classes of coverage which include dense, medium and sparse. Ground validation through observation was also conducted to validate these vegetation coverage classes.

\section{Beach Slope}

Beach slope was measured through visual observation along the study region. Measurement was done at random points particularly on areas which has a significant difference in slope using a clinometer. Classification of the slope was done based on the USSSM slope classes. 


\section{Beach Width}

Measurement of the beach width was done using a roll meter at random points particularly on areas which has a significant width. The measurement of the beach width started from the vegetated area towards the tidal line.

\section{Beach Sand}

Sand samples from the vegetated areas were taken at random points for each study stations using a PVC pipe of $60 \mathrm{~cm}$ in length and 10 inch in diameter. The pipe was penetrated into the sand at a depth between $35-40 \mathrm{~cm}$. Samples were kept in a plastic container and brought to the FPIK-IPB laboratory for analysis. The classification of the sand in this study was done based on the USDA standard classification of sand particles.

\section{Sand Moisture}

Sand moisture was measured random points on vegetated area for each study stations using soil moisture meter ETP306 at depth ranging between $35-40 \mathrm{~cm}$. Measurement was conducted for 18 days, four times each day at $6 \mathrm{am}$ in the morning, $12 \mathrm{pm}$ in the afternoon, $6 \mathrm{pm}$ in the evening and $12 \mathrm{am}$ at night.

\section{Sand Temperature}

Sand temperature was measured at random points near the vegetated areas for each study stations using a digital thermometer. The thermometer was placed inside the sand at depth between $35-40 \mathrm{~cm}$. Measurement was conducted for 18 days, four times each day at $6 \mathrm{am}$ in the morning, $12 \mathrm{pm}$ in the afternoon, $6 \mathrm{pm}$ in the evening and $12 \mathrm{am}$ at night.

\section{Seagrass}

Data on the type of seagrass and the percentage of coverage were collected by placing a 50 x 50 quadrant transect plot randomly on the seagrass area.

\subsubsection{Secondary Data}

Secondary data are supporting data obtained from the UPTD Pangumbahan, thesis or dissertation. This also includes the general information of the study region, the boundary of conservation area in Pangumbahan and data on the green turtles' trend coming ashore in previous years as well as other related documents.

\subsection{Data Analysis}

The spatial habitat suitability map was developed based on the ecological parameters of the green turtles' habitat; each has a different level of influences to the green turtle habitat suitability.

This was illustrated by the different scores and weights given to each of these parameters which was based on the importance of the parameters. The green turtles distribution preferences is presumed as their habits and behaviors which are the dominant parameters in comparison to other parameters as this is an instinctive behavioral that exists in green turtles. The suitability matrix was developed as a based for the spatial analysis using scoring and weighing methods. Based on the literature review and discussion with experts, a habitat suitability matrix of green turtle was created as shown in table 2.

Spatial analysis was conducted with Geographical Information System (GIS) using overlay method (overlay analysis), classifycation, weighting and scoring.

Scoring was done based on the suitability value of green turtle nesting habitat. The weight shows the level of the parameter influence to the green turtle. The outcome of the spatial analysis is a habitat suitability map for green turtle with three different classes of suitability which includes very suitable (S1), suitable (S2) and unsuitable (S3). 
Table 2. Green turtle sabitat suitability matrix.

\begin{tabular}{|c|c|c|c|c|c|c|c|}
\hline \multirow{2}{*}{ Parameter } & \multirow{2}{*}{ Weight } & \multicolumn{2}{|c|}{ S1 } & \multicolumn{2}{|l|}{ S2 } & \multicolumn{2}{|c|}{ S3 } \\
\hline & & Class & Score & Class & Score & Class & Score \\
\hline $\begin{array}{l}\text { No.turtles /Research } \\
\text { location/6 months } \\
\text { (n) }\end{array}$ & 22 & $>87$ & 3 & $58-87$ & 2 & $<58$ & 1 \\
\hline $\begin{array}{l}\text { Percentage of beach } \\
\text { vegetation cover } \\
(\%)\end{array}$ & 20 & $>70$ & 3 & $50-70$ & 2 & $<50$ & 1 \\
\hline Beach slope $\left(^{\circ}\right)$ & 14 & $10-25$ & 3 & $\begin{array}{l}0-10 \text { and } \\
>25-30\end{array}$ & 2 & $>30$ & 1 \\
\hline Beach width (m) & 14 & $30-80$ & 3 & $80-150$ & 2 & $\begin{array}{l}<30 \text { and } \\
>150\end{array}$ & 1 \\
\hline $\begin{array}{l}\text { Percentage of sand } \\
\text { coverage }(\%)\end{array}$ & 10 & $>90$ & 3 & $45-90$ & 2 & $<45$ & 1 \\
\hline Sand moisture $(\%)$ & 10 & $20-30$ & 3 & $10-<20$ & 2 & $\begin{array}{l}<10 \text { and } \\
>30\end{array}$ & 1 \\
\hline $\begin{array}{l}\text { Sand temperature } \\
\left({ }^{\circ} \mathrm{C}\right)\end{array}$ & 10 & $25-32$ & 3 & $\begin{array}{l}22-24 \text { and } \\
33-35\end{array}$ & 2 & $\begin{array}{c}<22 \text { and } \\
>35\end{array}$ & 1 \\
\hline$\sum$ (Weight $x$ Score $)$ & & & & 200 & & 10 & \\
\hline
\end{tabular}

Modification: Lizarraga et al. (2013), Yamamoto et al. (2012), Ozdilek et al. (2007), Nuitja (1992), Mc.Gehee (1990), and Goin et al. (1978).

\section{RESULT AND DISCUSSION}

\subsection{Spatial Analysis of Green Turtle Habitat}

The total number of green turtle recorded in Pangumbahan beach within 6 months (Januari - June 2015) was a total of 219. The frequency of turtle coming ashore was at the highest in station 2 which was 87 turtles, while no observation of turtle nestling in station 0. It was likely that these green turtles which came to Pangumbahan beach were turtles from the previous hatchlings from the same area. The high frequency of green turtles visiting this area were also likely due to their habits and behaviors of having a tendency to visit their former birth place. Nuitja (1992) stated that there have been strong evidences that showed the tendency of a green turtle to come back to its former birth place and nestled there. This was based on her observation that showed almost $92,16 \%$ of the tagged green turtles came back to the same place, however, had choose to find new nestling area when the former habitat was damaged.

The vegetated area on Pangumbahan beach is 78,7 hectare or $60,81 \%$ out of the total area and is dominated by Pandanus tectorius along the beach. This vegetation grows densely in stations 2 and 3, while on other station the growth is less dense. Based on our observation, we concluded that turtles prefer to nest under dense vegetation compare to other area where Pandanus tectorius growth is less dense. Nuitja (1992) stated the Green turtles favored a nesting ground on a beach which is dominated by vegetation of Pandanus tectorius species and Turkozan et al. (2011) which states that vegetated area has the highest success ratio of eggs hatching.

Approximately $84,7 \%$ of the Pangumbahan beach is dominated with sand particles of medium and fine sized ranging from $0 \mathrm{~mm}$ to $0,5 \mathrm{~mm}$, with an average of 
slope of $9^{\circ}$ ranging from gentle slope to steep categories and having an average of beach width of $78,22 \mathrm{~m}$. Areas which are further south in station 0 are dominated with rough sand grains, medium slope degree and with narrower beach width ranging from $16 \mathrm{~m}$ $21 \mathrm{~m}$. Areas in stations 2 and 3 are dominated with fine and medium sand grains with beach width ranging between $21 \mathrm{~m}$ $81 \mathrm{~m}$ and higher slope degree. The northern areas of the beach (areas in stations 4 to 6) have wider beach with ranging between $81 \mathrm{~m}$ to $41 \mathrm{~m}$ and higher slope degree and undulating surface and are dominated with fine sand grains. Lizarraga et al. (2013) stated that some conditions such as width and length of the beach, vegetation types and beach slope affect the probability of turtle nesting. Turtle favour sandy beach with $90 \%$ sand coverage of medium and fine sized (Nuitja, 1992), good air circulation (Ackerman, 1980), low salinity and high moisture (Miller et al., 2003). Yamamoto (2012) provide an optimum range of beach width ranging from $40-50 \mathrm{~m}$ with slope ranges between $0,06^{\circ}-22,34^{\circ}$

The average sand moisture for Pangumbahan beach was $26 \%$ with an average temperature of $29^{\circ} \mathrm{C}$. Sand moisture and temperature was deemed to be average along the area, except in the southern portion (areas in station 0) which showed fluctuation in temperature and extreme humidity. Furthermore, the narrow beach width in these areas had caused tidal submergence and affect the stability of the sand moisture and temperature as well as the success of the hatching of the nests. It was likely that these became the reasons for the green turtles to opt to nest in areas located in stations 1 to 6 only. The choice of location is closely related to the tides and sand moisture (Hitchins et $a l ., 2003)$ and hence the primary affecting factor in determining a nesting location is to avoid submergence of turtle eggs by the tide (Lizarraga et al., 2013). However, the size of sand grains has greater effects on many of the important parameters that determine success of the incubation process such as porosity, moisture and density of the sand (Stancyk and Ross, 1978; Mortimer, 1990, Chen et al., 2010). Turtle embryos are very susceptible to three environmental conditions, namely humidity, air circulation in the nest and temperature (Ackerman, 1977, 1991, 1980; Mortimer, 1990; Packard and Packard, 2002). The optimum sand moisture for hatching is $25 \%$ (McGehee, 1990). The embryo has been proved to be highly vulnerable to extreme temperature (Howard, et al., 2014) in which the optimal temperature growth range is between $24^{\circ} \mathrm{C}-33^{\circ} \mathrm{C}$ (Dermawan et al., 2009). Goin et al. 1978 stated that the optimum temperature for the development of turtle egg embryo ranges between $25^{\circ} \mathrm{C}-32^{\circ} \mathrm{C}$, and this optimum temperature will affect the sex ratio of the hatchlings (Broderick et al., 2001).

Seagrasses in Pangumbahan beach is categorize as damaged (less healthy) with an average of coverage of $42,81 \%$ and dominated by Thalasia hemprichi and Cymodocea Serrulata. Seagrass is getting highly damageed due to human activities on the coastal area (Fourqurean et al., 2001). The existence of seagrass is really important for turtles. Regardless of the seagrass species in an area, the green turtle will often be the dominating species in that particular area (Ballorain et al., 2010). Distribution of the parameters are shown in Figure 1 and 2. 


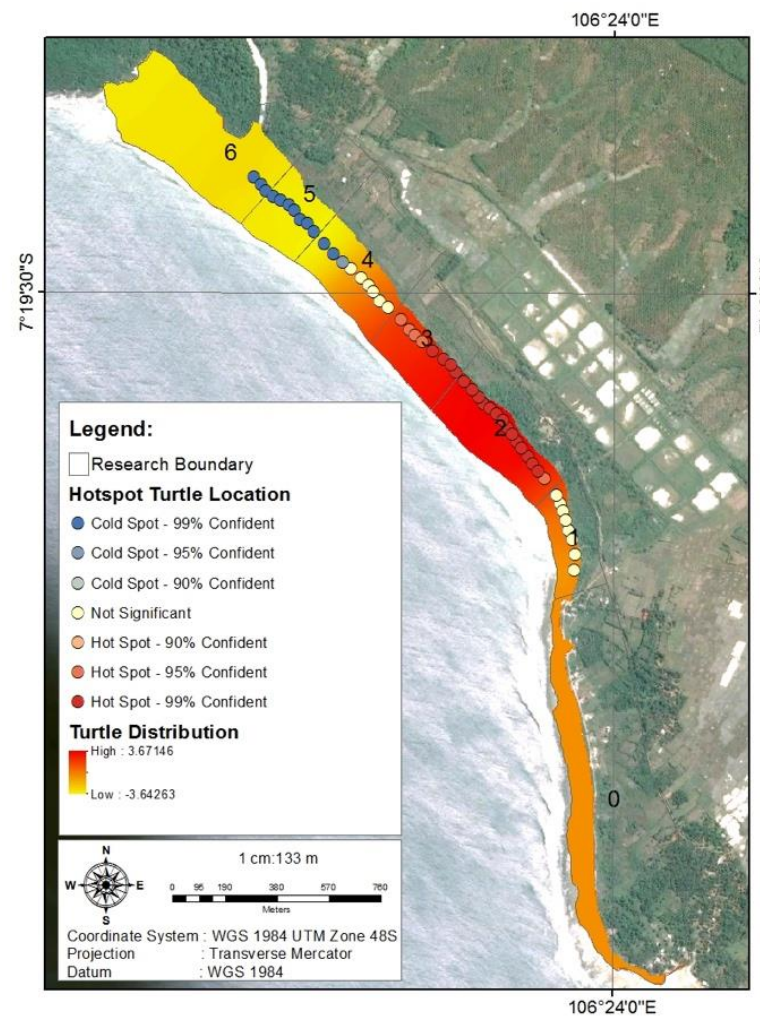

(a)

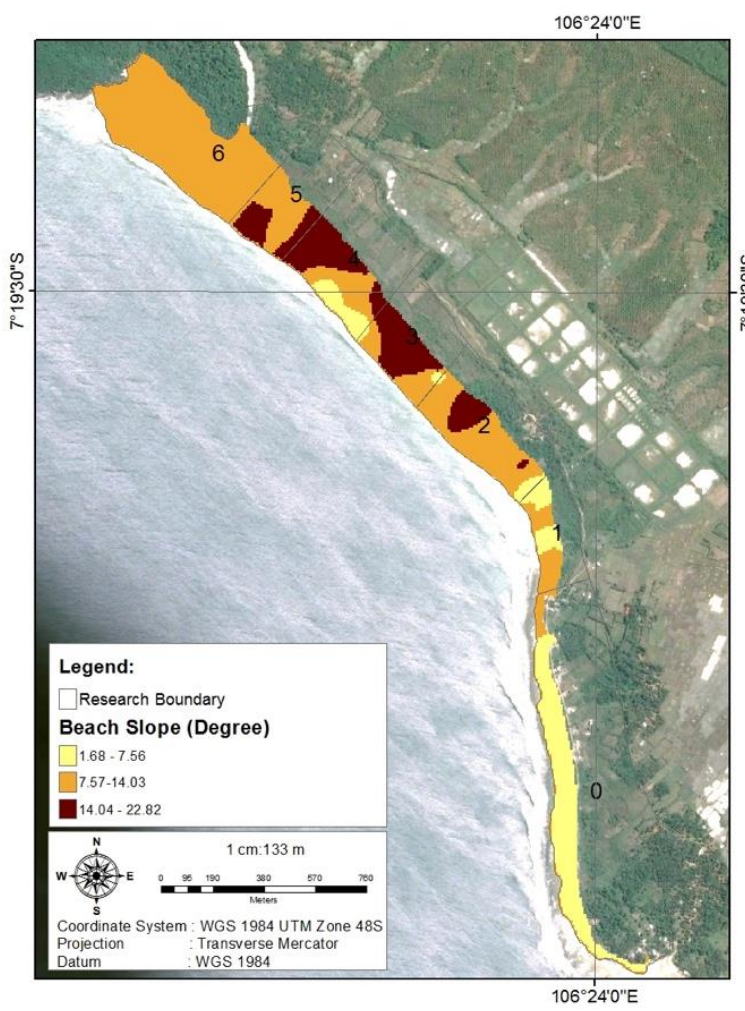

(c)

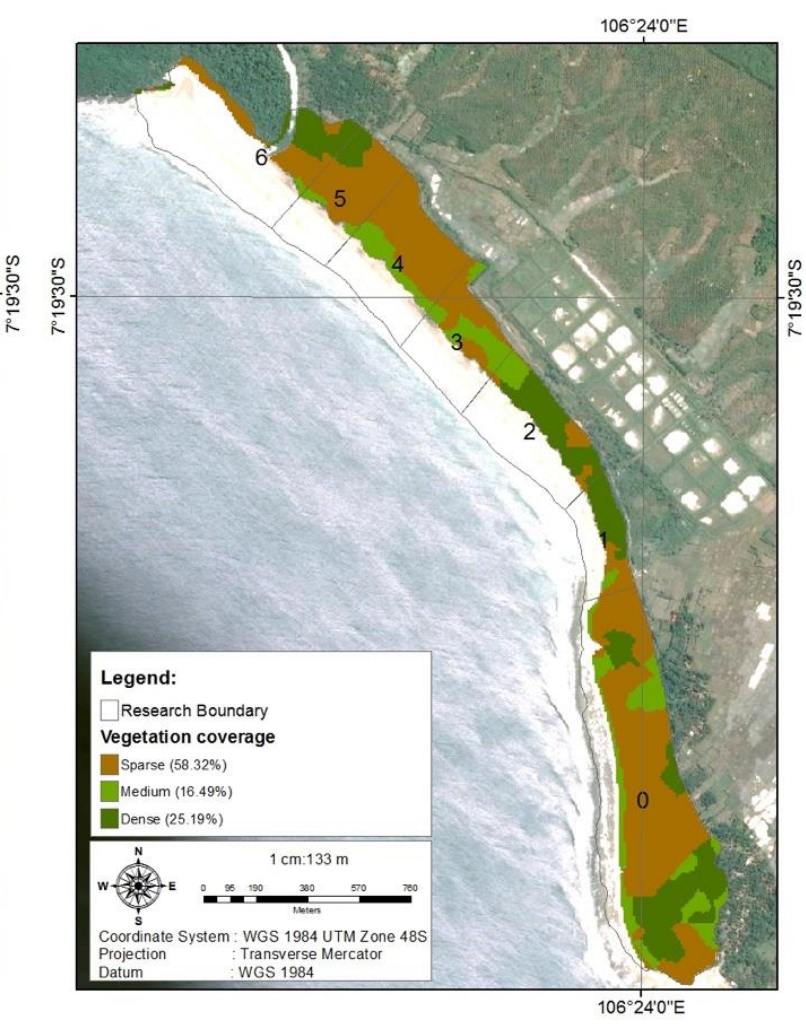

(b)

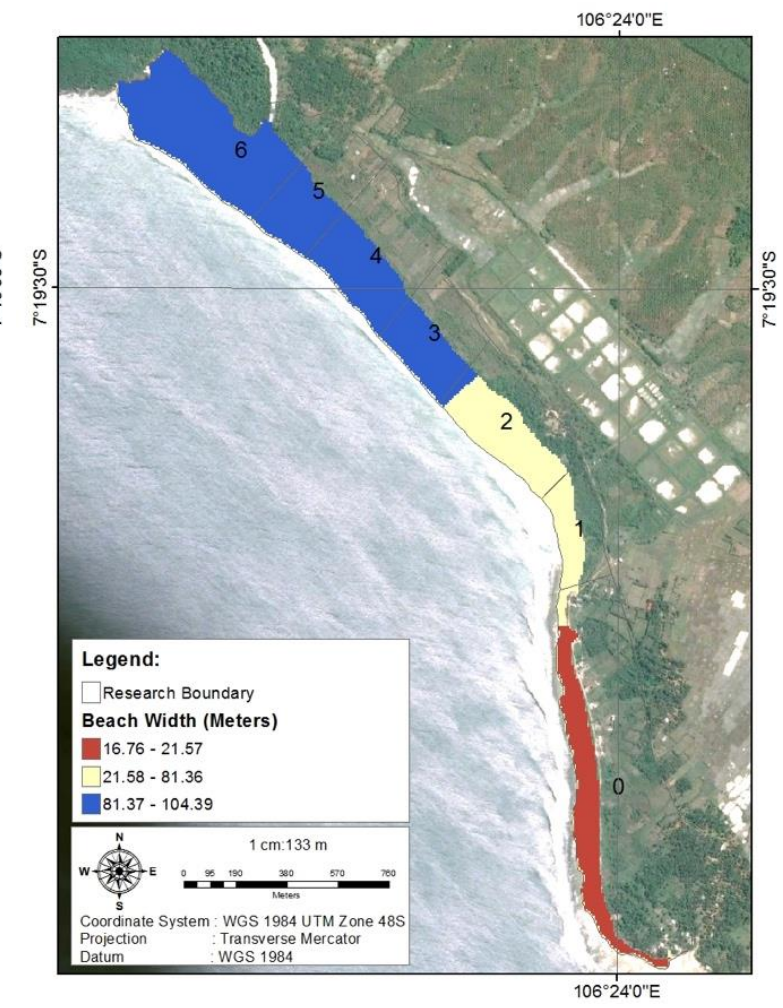

(d)

Figure 1. (a). Green turtle preferences distribution, (b). Composition of beach vegetation coverage, (c). Beach slope charateristics (d). Beach width characteristics. 
Habitat Suitability and Zoning Analysis for Green Turtle...

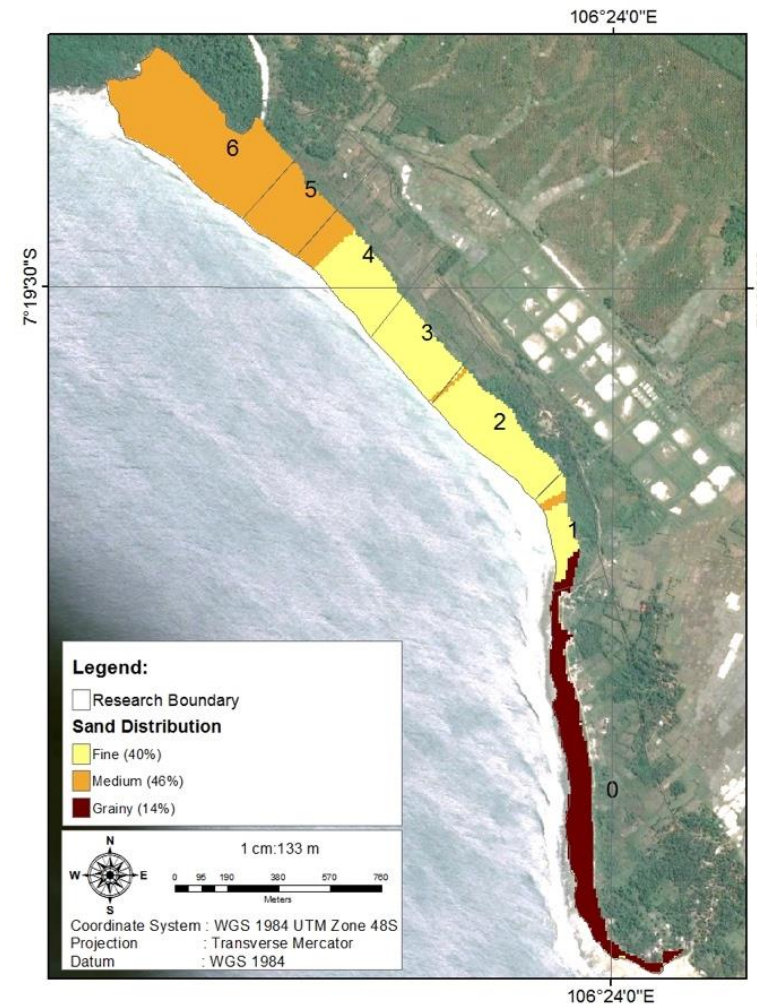

(a)

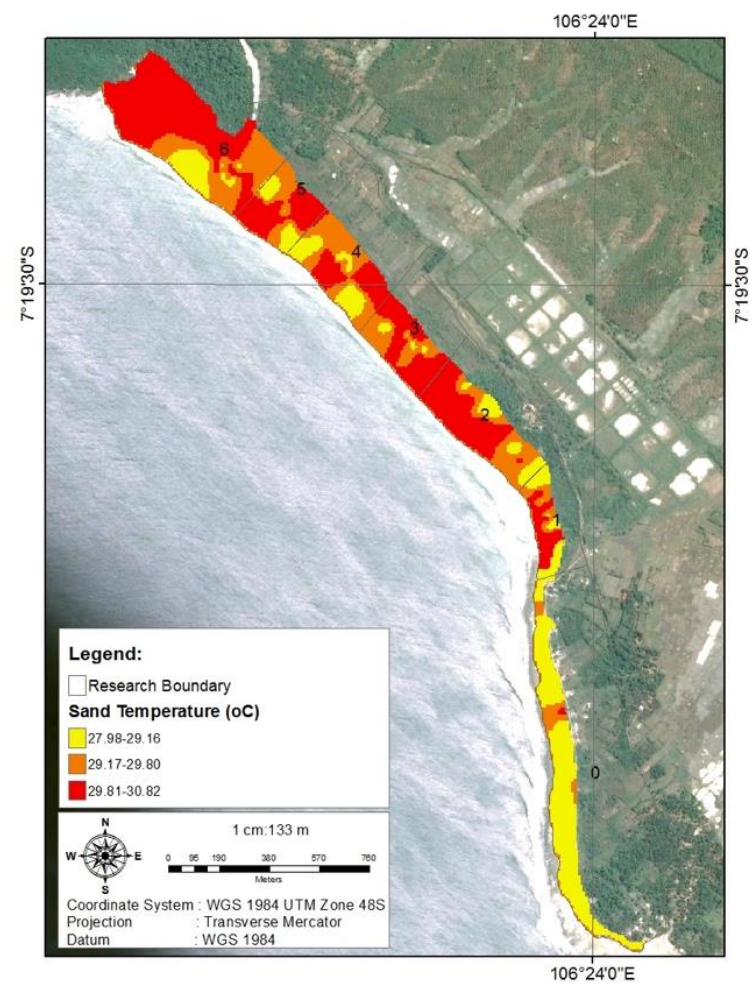

(b)

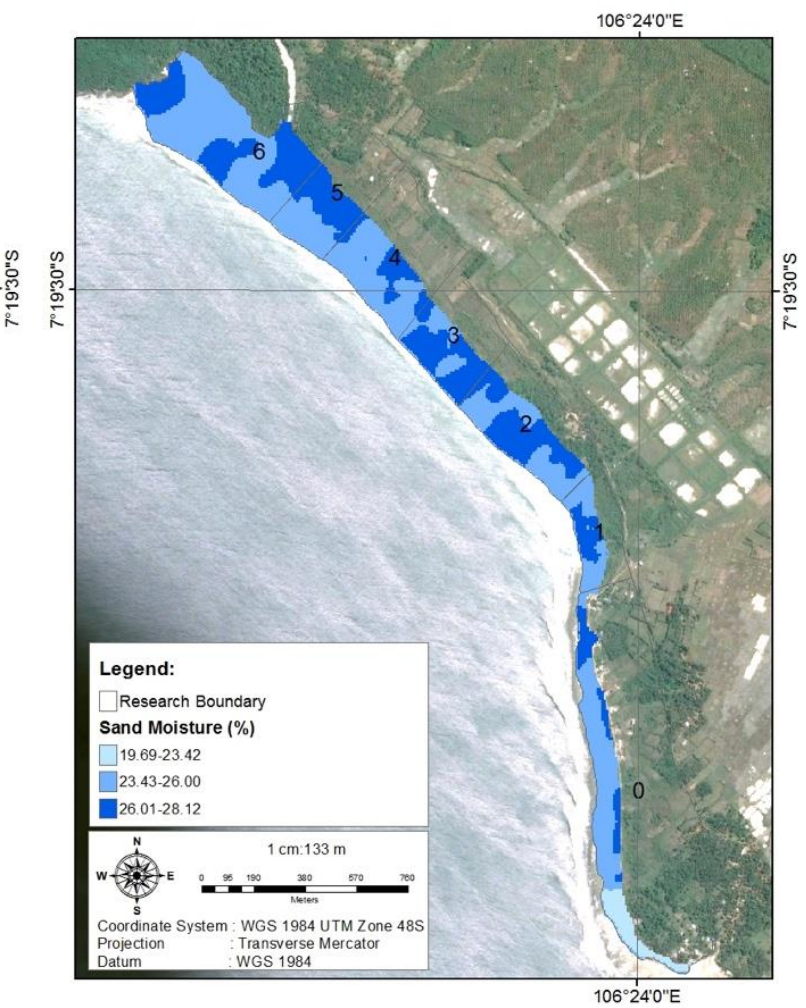

(b)

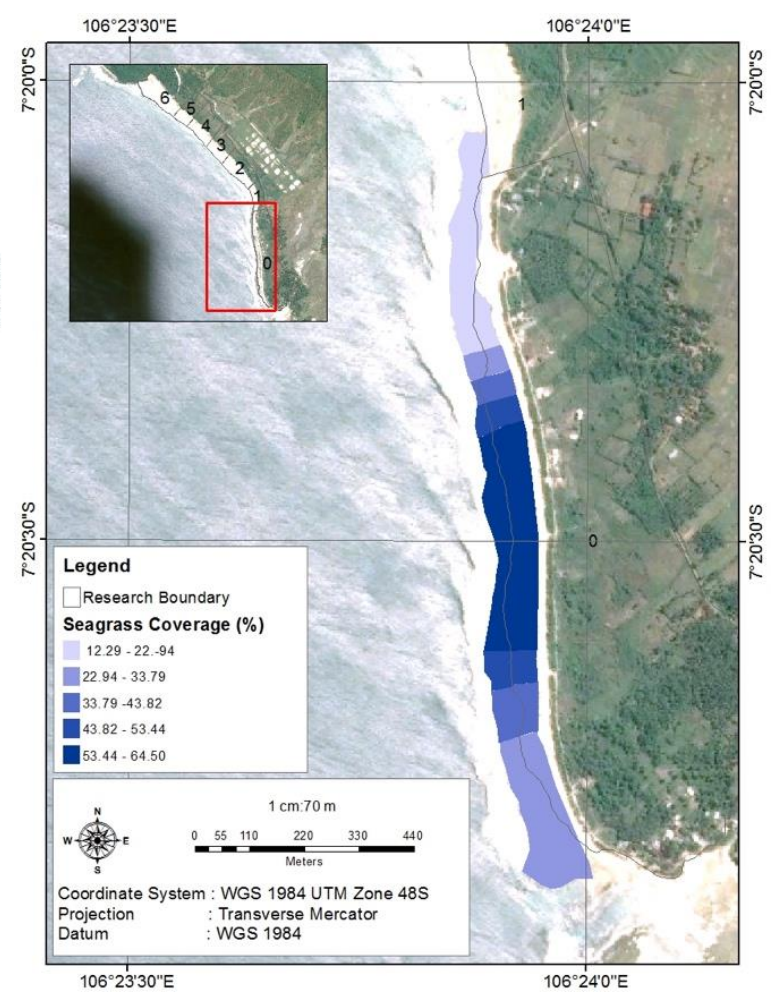

(d)

Figure 2. (a). Composition of medium and fine size of sand texture distribution, (b). Sand moisture distribution (c). Sand temperature distribution (d). Distribution of seagrass. 


\subsection{Green Turtle Habitat Suitability}

Based on the findings and observations in this study, it can be concluded that nesting locations for the green turtle in Pangumbahan beach was mainly influenced by physical factors of the beach which is more visual compare to non physical factors (such as humidity and temperature). Our observations showed that green turtle has the tendency to choose nesting habitat which is characterized by sandy beach and is predominated by medium and fine sand particles with dense vegetation coverage of pandanus tectorius that grow in clusters and with medium beach width and is free from sea water submergence but at the same time not too far away from the tidal line while areas that have thin vegetation coverage with undulated beach slope are less preferable by green turtles (Figure 3).

The green turtle habitat suitability produced a suitability classes between134268 . The suitability area of each models are shown in Table 2.

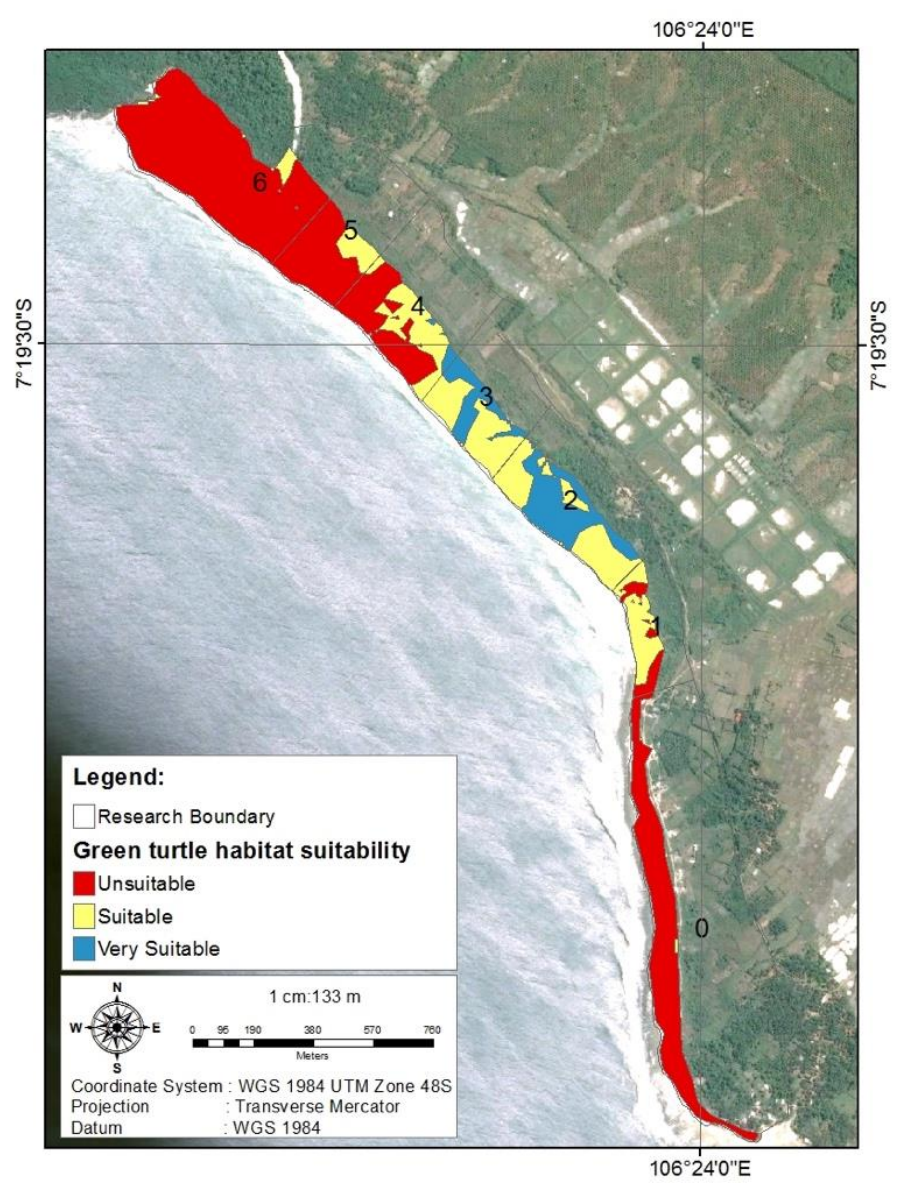

Figure 3. Green turtle habitat suitability.

Table 2. Green turtle habitat suitability class in Pangumbahan Turtle Park.

\begin{tabular}{clccc}
\hline No & Suitability Class & Range & Area $(\mathrm{Ha})$ & Area $(\%)$ \\
\hline 1 & Unsuitable & $134-178,67$ & 37,21 & 63,36 \\
2 & Suitable & $178,68-223,34$ & 14,60 & 24,87 \\
3 & Very suitable & $223,35-268$ & 6,91 & 11,77 \\
\hline
\end{tabular}


Areas which fall with the most suitable and suitable classes were found mainly in Stations 2 and 3 which are located in the center of Pangumbahan beach. Suitability of habitat decreases towards the south and north of the beach as the beach width becomes wider. The model also indicate there are areas within stations 1 and 4 that falls under the suitable classification. Areas within Stations 5 and 6 which are located further north of the beach are likely unsuitable as the green turtles habitat. This can be concluded that areas in stations 2 and 3 are the most suitable habitat for the green turtles compare to areas in other stations. In relation to the purpose of this spatial model which is to established a conservation zoning system in accordance to the Ministerial Decree no.17/2008, stations 2 and 3 are qualified as the core zone areas.

\subsection{Evaluation and Recommendations}

The Pangumbahan Turtle Park is categorized as marine conservation area which is established and designated for the purpose of the conservation and protection of green turtle as well as a tourist site. Currently the zoning within the conservation area consist of core zone, limited use zone and other zones. Station 4 and 5 are designated as the core zones while other stations function as zones for tourism purposes. The unsuitable zoning arrangement that exist currently result in the conflict between tourists and the turtles that come to Station 2 and 3. Determination of the zones in a conservation area which does not comply with the zoning policy criteria in addition to violating the rules will also have a negative impact on the sustainability of ecosystems and species therein. It is likely that there will be a decrement in the green turtle population within the conservation area due to the interaction of human and green turtles if the current existing zone are not revised. The number of tourist arrivals is considered as a threat to the turtles which they should avoid, and is likely causing changes of the habitat environment (e.g. rubbish pollution, light and noise pollution, etc) as well as the threshold of tolerance of the turtles and eventually causing areas in station 2 and 3 which were previously suitable for turtles now turned to unsuitable. This condition is seen with the downward trend in the population of green turtles nesting in this area from year to year. The population of green turtles nesting on the Pangumbahan Turtle Park tends to decrease (Haryanti, 2014). This proves the existence of a discrepancy between the existing zoning with green turtle habitat suitability that should be.

The result of the habitat suitability spatial analysis showed that the most suitable area for green turtle nesting habitat are located within station 2 and station 3 . The high frequency of turtles choosing to nest at stations 2 and 3 also denotes that both stations still have the characteristic of a natural ecosystems and can be interpreted as a source of germplasm for conservation area of Pangumbahan turtle park which is one of the condition for an area designated as the core zone according to Ministerial Decree no.17/2008. Given the condition of other dominant stations falls under the unsuitable class, it is a possibility that the green turtle which previously choose to nest in Pangumbahan beach will move to find other nesting location in other region since their previous nesting location are not suitable for nesting anymore. Therefore, it is important to protect area that is rich in diversity (Fadini et al., 2011).

Taking into consideration of each station, the result of the spatial suitability of green turtle in Pangumbahan beach and in accordance with the criteria and requirements of the determination of the zones within marine conservation areas, it is more suitable to place the core zone in at stations 2 and 3 (including the marine area along Pangumbahan beach since this area are turtles feeding ground). Stations 6 and 1 which is located on the estuary with high sedimentation is not suitable for turtle nesting due to 
the sedimentation characteristics that can affect the duration of the incubation and the growth of the embryo (Fadini et al., 2011). Stations 5 and 6 which fall under the unsuitable class and with wider beach width and flat contour are likely to be a better spot for tourists to enjoy sunset view and to do recreational activity on the beach freely. Station 0 which also falls under the unsuitable class can also serves as a location for tourists for outdoor activities with the support of existing public facilities such as roads and lodges while the sea area of this station can be used as a rehabilitation zone and protection of seagrass. In the context of landscape, located near to this area is another green turtle conservation area, the Cikepuh conservation area. It is likely that the Cikepuh conservation area affects the number of green turtle population at Pangumbahan beach and is most likely to be an alternative options for the green turtle to nest and vice versa. Hence, involvement and participation from the Cikepuh conservation area management in Pangumbahan Turtle Park's management are deemed to be important.

The revision of the zones will certainly create a positive impact on the changes of the area management patterns such as tourist visits will no longer be at zone 2 and 3. Information on the new zoning system will need to be informed and disseminated among the nearby local communities by creating an information board about the new zone boundaries as well as information providing information and education related to what can and cannot be done within each zone. By doing proper zoning arrangement, the effectiveness of management of a conservation area can be achieved. The existing zones and recommendation of Pangumbahan Turtle Park are shown in Figure 4 and Figure 5.
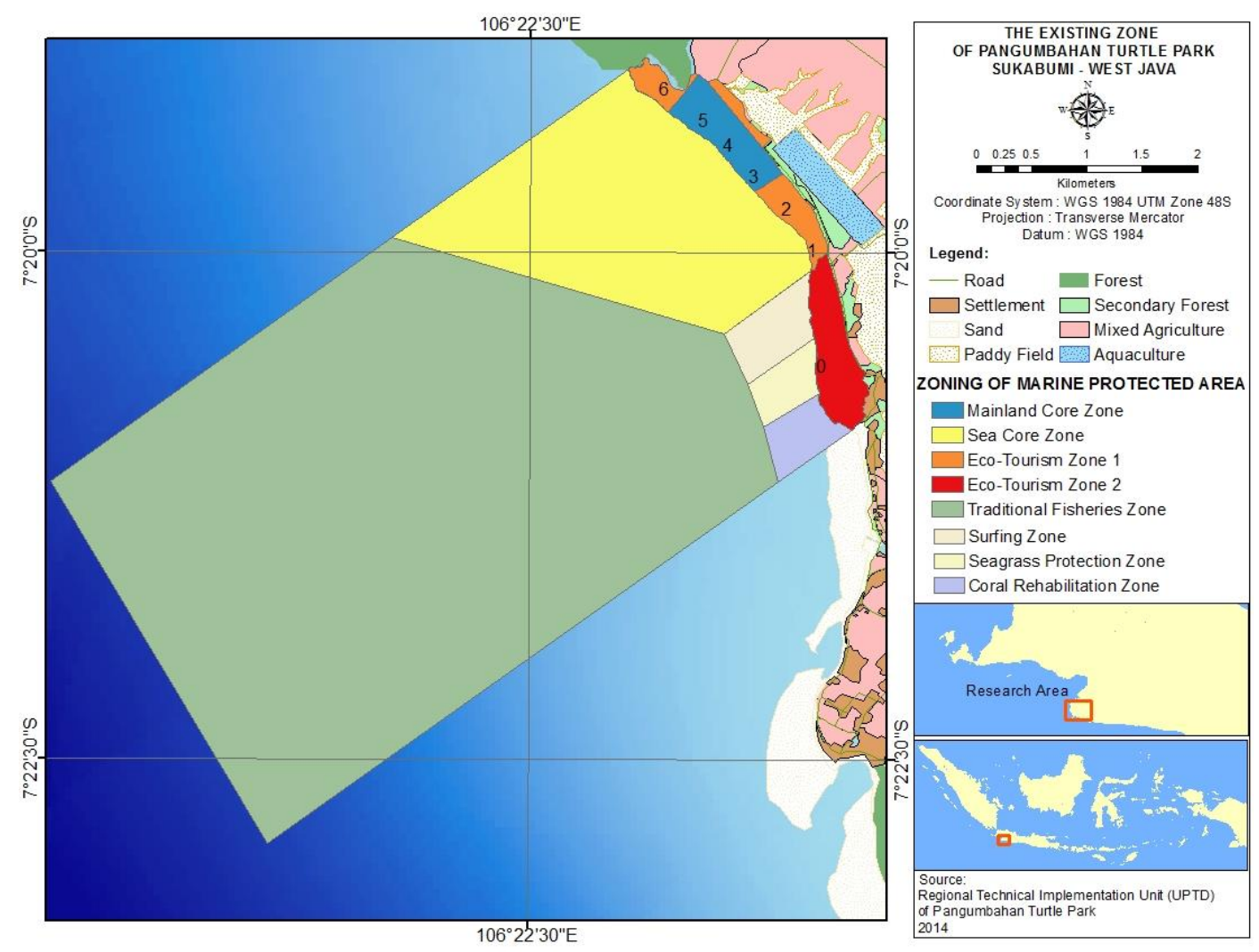

Figure 4. The existing zone of Pangumbahan Turtle Park. 

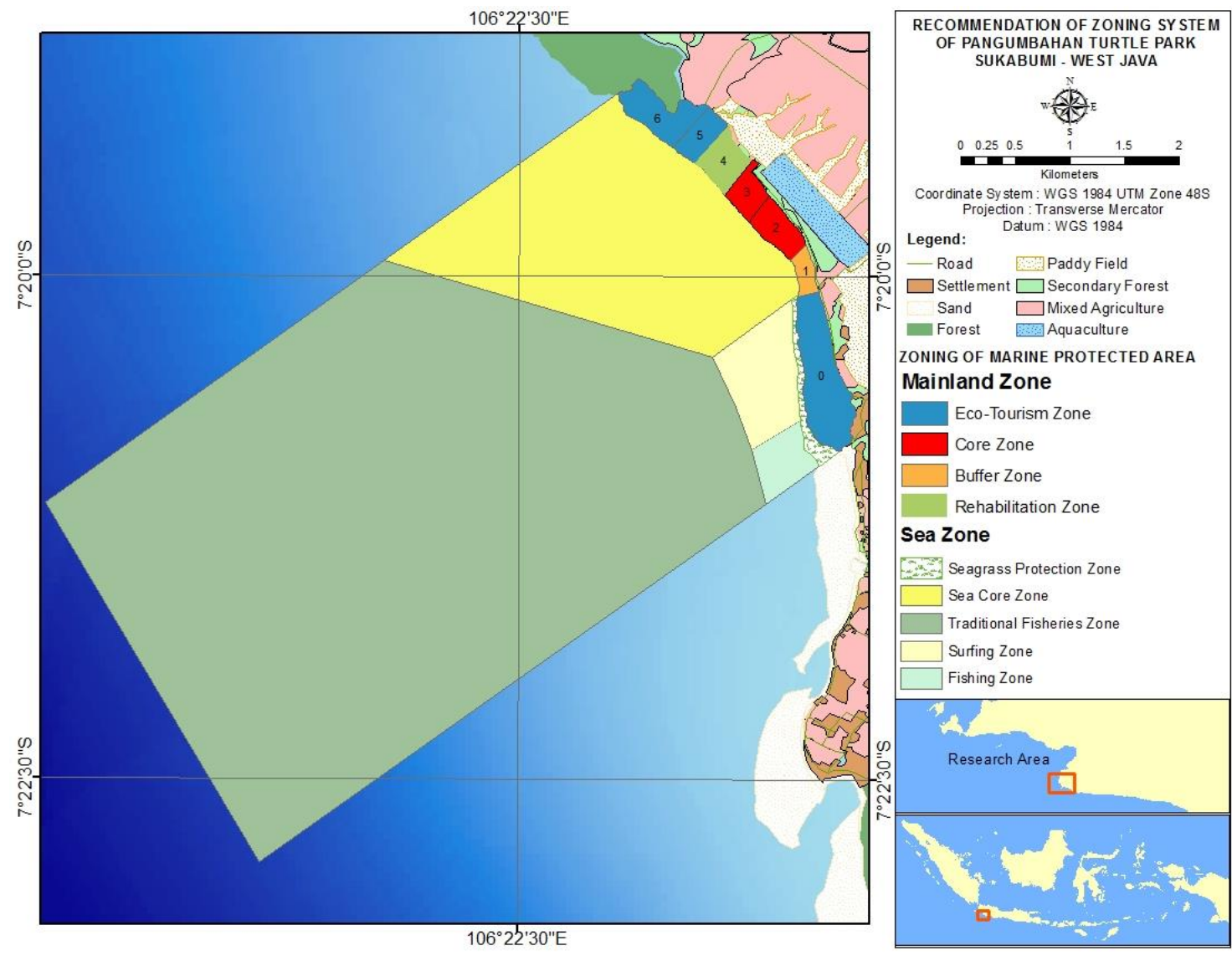

Figure 5. Recommendation of Zoning System of Pangumbahan Turtle Park.

\section{CONCLUSION}

The most suitable area for the green turtle habitat in Pangumbahan beach was measured at 6,91 hectar, 14,60 hectar for the suitable areas and 37,21 for the unsuitable areas. The most suitable areas for the green turtle nestling habitat are located in the middle of the beach which are located in stations 2 and 3.

The current existing zones needs to be revised using the recommended zoning system of Pangumbahan Turtle Park, in which, areas in stations 2 and 3 including the sea along the coast should be zoned as the core zone. Areas in stations 0,5 and 6 should remained as limited zone for the purpose of conservation, while the sea area in station 0 as seagrass rehabilitation and protection zone and stations 1 and 4 as other zone which are rehabilitation zone and buffer zone for the protection of turtles.

\section{REFERENCES}

Ackerman, R.A. 1980. Physiological and ecological aspects of gas exchange by sea turtle eggs. American Zoologist, 20:575-583.

Ackerman, R.A. 1991. Physical factors affecting the water exchange of buried eggs. Physical Influences on Embryonic Development in Birds and Reptiles. Ferguson, M.J.W., and D.C. Deeming (Eds.). Cambridge University Press, New York, USA. 193211pp.

Ackerman, R.A. 1977. The respiratory gas exchange of sea turtle nests (Chelonia, Caretta). Respiration Physiology, 31(1):19-38.

Ackerman, R.A., R.C. Seagrave, R. Dmi'el, and A. Ar. 1985. Water and heat exchange between parchment sheller 
reptile eggs and their surroundings. Copeia, 1985:703-711.

Ballorain, K., S. Ciccione, J. Bourjea, H. Grizel, M. Enstipp, and J.Y. Georges. 2010. Habitat use of a multispecific seagrass meadow by green turtles Chelonia mydas at Mayotte Island. Mar Biol., 157:2581-2590. DOI:10. 1007/s00227-010-1520-7.

Bjorndal, K.A., A.B. Bolten, and M.Y. Chaloupka. 2005. Evaluating trends in abundance of immature green turtles, Chelonia mydas, in the greater caribbean. Ecological Applications, 15(1):304-314.

Broderick, A.C., B.J. Godley, and G.C. Hays. 2001. Metabolic heating and the prediction of sex ratios for Green Turtles (Chelonia mydas). Physiological and Biochemical Zoology, 74(2):161-170.

Chen, C.L., C.C. Wang, and I.J. Cheng. 2010. Effects of biotic and abiotic factors on the oxygen content of green sea turtle nests during embryogenesis. J. Comp Physiol B., 180: 1045-1055. DOI:10.1007/s00360-010 $-0479-5$.

Cheng, I.J., C.T. Huang, P.Y. Hung, B.Z. Ke, C.W. Kuo, and C. Ling. 2009. Ten years of monitoring the nesting ecology of the Green Turtle, Chelonia mydas, on Lanyu (Orchid Island), Taiwan. Zoological Studies, 48(1):8394.

Dermawan, A., I.N.S. Nuitja, D. Soedharma, M.H. Halim, M.D. Kusrini, S.B. Lubis, , R. Alhanif, M. Khazali, M. Murdiah, and P.L. Wahjuhardini. 2009. Pedoman teknis pengelolaan konservasi penyu. Direktorat Konservasi dan Taman Nasional Laut, Direktorat Jenderal Kelautan, Pesisir dan Pulau-Pulau Kecil, Departemen Kelautan dan Perikanan. Jakarta. $123 \mathrm{hlm}$.

Fadini, L.S., A.G. Silva, and P.D. Ferreira. 2011. Sedimentary characteristics and their effects on hatching success and incubation duration of Caretta caretta (Testudines: Cheloniidae) in Espirito Santo, Brazil. Zoologia, 28(3):312320. DOI:10.1590/S19844670201100 0300005.

Fourqurean, J.W., A. Willsie, C.D. Rose, and L.M. Rutten. 2001. Spatial and temporal pattern in seagrass community composition and productivity in south Florida. Marine Biology, 138:341354.

Fujisaki I, K.M. Hart, and A.R. Sartain. 2016. Habitat selection by green turtles in a spatially heterogeneous benthic landscape in Dry Tortugas National Park, Florida. Aquatic Biology, 24:185-199. DOI: 10.3354/ ab00647.

Geneletti, D. and I.V. Duren. 2008. Protected area zoning for conservation and use: A combination of spatial multicriteria and multiobjective evaluation. Landscape and Urban Planning, 85:97110.

Goin, C.J., O.B. Goin and G.R. Zug. 1978. Introduction to Herpetology, ( $3^{\text {rd }}$ Ed.). W.E. Freeman and Co, San Fransisco. 378p.

Haryanti, R. 2014. Status populasi penyu hijau (Chelonia mydas, Linnaeus 1758) di taman pesisir pantai penyu Pangumbahan, Kabupaten Sukabumi, Jawa Barat. Skripsi. Departemen Manajemen Sumberdaya Perairan. Fakultas Perikanan dan Ilmu Kelautan. Institut Pertanian Bogor, Indonesia. $21 \mathrm{hlm}$.

Hitchins, P.M., O. Bourquin, S. Hitchins, and S.E. Piper. 2003. Factors influencing emergences and nesting sites of hawksbill turtles (Eretmochelys imbricata) on Cousine Island, Seychelles, 1995-1999. Phelsuma, 11:59-69.

Howard, R., I. Bell, and D.A. Pike. 2014. Thermal tolerances of sea turtle embryos: current understanding and future directions. Inter research, 26:75- 
86. DOI: $10.3354 /$ esr00636.

IUCN. 2004. The IUCN red list of threatened species: Chelonia mydas, Assessment by Seminoff, J.A. (Southwest Fisheries Science Center, U.S.). The IUCN red list of threatened species, DOI:10.2305/IUCN.UK.2004.RLTS. T4615A11037468.en. 21p.

Lizarraga, L.Z. and J.E.M. Mavil. 2013. Nest site selection by the green turtle (Chelonia mydas) in a beach of the north of Veracruz, Mexico. Revista Mexicana de Biodiversidad, 84:927937.

Mcgehee, M.A. 1990. Effects of moisture on eggs and hatchlings of loggerhead sea turtules (Caretta caretta). Herpetologica by The Herpetologists L'eague, Inc., 46(3):251-258.

Miller, J.D., C.J. Limpus, and M.H. Godfrey. 2003. Nest Site Selection, Oviposition, Eggs, Development, Hatching, and Emergence of Loggerhead Turtles. sip.bolton. 125p.

Mortimer, J.A. 1990. The Influence of beach sand characteristics on the nesting behavior and clutch survival of green turtles (Chelonia mydas). American society of ichthyologists and Herpetologists. Copeia, 1990(3):802-817.

Nuitja, I.N.S. 1992. Biologi dan ekologi pelestarian penyu laut. Institut Pertanian Bogor. 128hlm.

Ozdilek, S.Y., H.G. Ozdilek, F.S. Ozaner. 2007. Possible influence of beach sand characteristics on green turtle
Nesting Activity on Samandağ Beach, Turkey. Florida. J. of Coastal Research. West Palm Beach, 23(6): 1379-1390. DOI:10.2112/06-0630.1.

Packard, G.C., and M.J. Packard. 2002. Wetness of the nest environment influences cardiac development in pre and postnatal snapping turtles (Chelydra serpentine). Comp Biochem Physiol A., 132:905-912.

Stancyk, S.E. and J.P. Ross. 1978. An analysis of sand from green turtle nesting beaches on Ascension Island. Copeia, 1:93-99.

Turkozan, O., K. Yamamoto, and C. Y1lmaz. 2011. Nest Site Preference and Hatching Success of Green (Chelonia mydas) and Loggerhead (Caretta caretta) Sea Turtles at Akyatan Beach, Turkey. Chelonian Conservation and Biology, 10(2):270-275. DOI:http://dx.doi.org/10.2744/CCB0861.1.

Yamamoto, K.H., R.L. Powell, S. Anderson, and P.C. Sutton. 2012. Using LiDAR to quantify topographic and bathymetric details for sea turtle nesting beaches in Florida. Remote Sensing of Environment, 125:125-133. DOI: http://dx.doi. org/10.1016/j.rse.2012.07.016.
Diterime
: 3 Mei 2016
Direview : 14 Juni 2016
Disetujui : :22 Desember 2016 